\title{
Prognostic Value of the Uric Acid Level and Its Effect on Survival in Stage I-III Gastric Cancer
}

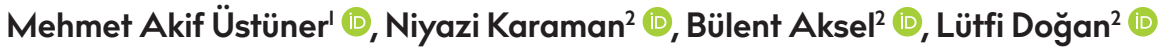 \\ 'Clinic of Gastroenterologic Surgery, Türkiye Yüksek İhtisas Training and Resarch Hospital, Ankara, Turkey \\ ${ }^{2}$ Clinic of General Surgery, Dr.Abdurrahman Yurtaslan Ankara Oncology Training and Resarch Hospital, Ankara, Turkey
}

ORCID IDs of the author:s M.A.Ü. 0000-0003-4087-555X; N.K. 0000-000I-9875-70I7; B.A. 0000-0002-2498-664X; L.D. 0000-0002-383409II.

Cite this article as: Üstüner MA, Karaman N, Aksel B, Doğan L. Prognostic Value of the Uric Acid Level and lts Effect on Survival in Stage I-III Gastric Cancer. Cyprus J Med Sci 2019; 4(3): 169-72.

\section{BACKGROUND/AIMS}

Uric acid is the product of purine metabolism. In this study, we investigated the prognostic value of serum uric acid value on disease-free and overall survival (DSF and OS) in gastric cancer.

\section{MATERIAL and METHODS}

The records of IIO patients who underwent surgery for Stage I-III gastric cancer between 2012 and 2014 were retrospectively analyzed.

\section{RESULTS}

The average follow-up period was 42 months in 110 patients studied. The mean age was $63.7 \pm 11.6$ years. Seventy percent of patients were male, and $43 \%$ underwent total and $57 \%$ subtotal gastrectomy. Most of gastric tumors were located in the distal stomach (56\%), $24 \%$ in cardia, and $19 \%$ in corpus. While the tumor size was found to be larger than $4 \mathrm{~cm}$ in $60 \%$ of the patients and larger than $8 \mathrm{~cm}$ in $20 \%$, according to the TNM system, II\% were Stage I, $29 \%$ Stage II, and 60\% Stage III. Metastatic/excised lymph node ratio is $<0.3$ in $59 \%$ of patients. The mean uric acid level was $4.63 \pm 1.44$. The cut-off values of uric acid were studied as 4 and 6 .

\section{CONCLUSION}

When the mean distribution of the OS and DFS values according to uric acid groups was examined, there was no statistically significant difference between the groups ( $p>0.05)$. In our study, while the uric acid value was not found to be effective in DSF and OS, the stage, metastatic lymph node ratio, tumor size, and localization were found to be effective factors in OS.

Keywords: Disease-free survival, gastric cancer, overall survival, serum uric acid

\section{INTRODUCTION}

Uric acid emerges as the final enzymatic product in the breakdown of purine nucleotides and is found free in humans and great apes. The purine catabolism in humans is the shortest one among vertebrates. Urate oxidase enzyme that converts uric acid to allantoin mutates in two steps. In other mammals, the end product of purine metabolism is allantoin, and it is eliminated by urine $(\mathrm{I}, 2)$. As a nucleic acid turnover product, uric acid increases rapidly in the growing diseased tissues of cancer patients (3). Therefore, it might be a prognostic marker in cancer patients. To the best of our knowledge, there are no studies in the literature examining the relationship between gastric cancer and serum uric acid value (SUA) in many years (4). In this study, we investigated the prognostic value on SUA on DF and OS in gastric cancer.

\section{MATERIALS and METHODS}

The records of 110 patients who underwent curative surgery (total/subtotal gastrectomy+D2 lymph node dissection) for Stage I-III stomach cancer between 2012 and 2014 and followed-up regularly were retrospectively analyzed. Patients with Gout's disease Gout, Stage IV patients treated with palliatively or with additional organ resection, histological types other than epithelial tumors, patients treated with neoadjuvant chemotherapy, emergent cases, patients who needed blood product transfusion in the perioperative period, patients that could not complete adjuvant therapy, and patients with preoperative infection were excluded from the study, because in these cases, SUA has already increased due to its anti-inflammatory properties. 
Patients were evaluated by medical oncology and radiotherapy specialists after the operation and received the necessary adjuvant treatments. Control examinations were held once every 3 months for the first 2 years of surgery and every 6 months for the following 3 years.

Other than history and physical examination, complete blood count, biochemical assays, and tumor markers (CEA, Ca 19-9) were studied at each control. Abdominal ultrasonography, computed tomography (CT), or upper gastrointestinal (GIS) endoscopy was performed in accordance with the patients' complaints. Abdominal radiologic imaging was performed once a year in patients with no complaints or examination findings. The age, gender, blood group, type of operation, pathology, tumor size, the number of pathologic lymph and total lymph nodes, and the TNM stage were recorded. Peripheral blood samples were collected approximately 2 weeks before surgery, and SUA values were recorded.

Ethics committee approval was received for this study from the local ethics committee of Dr. Abdurrahman Yurtaslan Training and Research Hospital (AOH 2017/10/17). Written informed consent was obtained from patients who participated in this study.

\section{Statistical Analysis}

Statistical calculations were performed using the Statistical Package for the Social Sciences for Windows v 16.0 (SPSS Inc:; Chicago, IL, USA). Fisher's exact test, Pearson's chi-squared, and Mann-Whitney $U$ analysis were used. The level of significance was set at $p<0.05$.

\section{RESULTS}

The average follow-up duration of 110 patients was 42 months, and the general characteristics are summarized in Table I. The mean age was $63.7 \pm 11.6$ years. Seventy percent of the patients were male, and $43 \%$ underwent total and $57 \%$ subtotal gastrectomy. Most of gastric tumors were located in distal stomach $(56 \%), 24 \%$ in cardia, and $19 \%$ in corpus, and $75 \%$ were reported as adenocarcinoma, $19 \%$ signed cell carcinoma, and 3\% mucinous carcinoma. While the tumor size was found to be $>4 \mathrm{~cm}$ in $60 \%$ of the patients and $>8 \mathrm{~cm}$ in $20 \%$, according to the TNM system, II\% were Stage I, 29\% Stage II, and $60 \%$ Stage III. The mean uric acid level was found to be $4.63 \pm 1.44$. The cut-off valves of uric acid were studied as 4 and 6 .

When the distribution of categorical variables according to the survival of cases is examined, there was a statistically significant difference between the groups in terms of the surgery type, tumor size, lymph node ratio, and disease stages $(p<0.05)$.

There was no statistically significant difference between the groups in terms of other variables ( $p>0.05$ ) (Table 2 ). Two different cut-off values as $2-4$ and $>4$ and $2-6$ and $>6$ were studied for uric acid levels. In both values, the uric acid levels had no a significant effect on OS and DFS (Table 3).

\section{DISCUSSION}

Uric acid occurs when the hypoxanthine and xanthine, which are the digestive consequence of foods and beverages contain- ing purine nucleoside in physiological pH, enter the enzymatic reaction with xanthine oxidoreductase (5). According to the hypothesis of Ames et al. (6), the increase in the level of uric acid in the blood gives an advantage to human beings.

\begin{tabular}{|c|c|c|c|}
\hline & & $\mathbf{n}$ & $\%$ \\
\hline \multirow[t]{2}{*}{ Gender } & Female & 33 & 30 \\
\hline & Male & 77 & 70 \\
\hline \multirow[t]{2}{*}{ Uric acid 4} & $2-4$ & 38 & 34.5 \\
\hline & $>4$ & 72 & 65.5 \\
\hline \multirow[t]{2}{*}{ Uric acid 6} & $2-6$ & 94 & 85.5 \\
\hline & $>6$ & 16 & 14.5 \\
\hline \multirow[t]{2}{*}{ Age 50} & $\leq 50$ & 13 & 11.8 \\
\hline & $>50$ & 97 & 88.2 \\
\hline \multirow[t]{2}{*}{ Age 70} & $\leq 70$ & 74 & 67.3 \\
\hline & $>70$ & 36 & 32.7 \\
\hline \multirow[t]{2}{*}{ Surgery type } & Total gastrectomy & 47 & 42.7 \\
\hline & Subtotal gastrectomy & hy 63 & 57.3 \\
\hline \multirow[t]{4}{*}{ Pathology } & Adenocarcinoma & 83 & 75.5 \\
\hline & Mucinous & 3 & 2.7 \\
\hline & Signet cell & 21 & 19.1 \\
\hline & Diffuse & 3 & 2.7 \\
\hline \multirow[t]{4}{*}{ Localization } & Cardia & 26 & 23.6 \\
\hline & Corpus & 21 & 19.1 \\
\hline & Antrum & 61 & 55.5 \\
\hline & Whole & 2 & 1.8 \\
\hline \multirow[t]{2}{*}{ Size 4} & $\leq 4 \mathrm{~cm}$ & 45 & 40.9 \\
\hline & $>4 \mathrm{~cm}$ & 65 & 59.1 \\
\hline \multirow[t]{2}{*}{ Size 8} & $\leq 8 \mathrm{~cm}$ & 88 & 80 \\
\hline & $>8 \mathrm{~cm}$ & 22 & 20 \\
\hline \multirow[t]{2}{*}{ Ratio 0.30} & $\leq 0.30$ & 66 & 60 \\
\hline & $>0.30$ & 44 & 40 \\
\hline \multirow[t]{2}{*}{ Ratio 0.60-0.90 } & $\leq 0.60$ & 90 & 81.8 \\
\hline & $>0.60$ & 20 & 18.2 \\
\hline \multirow[t]{4}{*}{ Stage } & 1 & 12 & 10.9 \\
\hline & $\|$ & 32 & 29.1 \\
\hline & III & 66 & 60 \\
\hline & & Mean $\pm S S$ & Median (Min.-Max.) \\
\hline Age & & $63.71 \pm 11.69$ & $63(34-85)$ \\
\hline Uric Acid & & $4.63 \pm 1.44$ & $4.45(2.1-1.2)$ \\
\hline Tm size & & $5.68 \pm 3.12$ & $5(0.5-15)$ \\
\hline Metastatic LN & & $5.98 \pm 6.87$ & $3(0-30)$ \\
\hline Total LN & & $18.42 \pm 8.3$ & $18(2-40)$ \\
\hline LN ratio & & $0.29 \pm 0.29$ & $0.19(0-0.9)$ \\
\hline OS & & $23.84 \pm 17.44$ & $22.5(1-62)$ \\
\hline DFS & & $22.47 \pm 17.67$ & $16(1-62)$ \\
\hline
\end{tabular}




\begin{tabular}{|c|c|c|c|c|c|c|c|}
\hline & & \multicolumn{2}{|c|}{ Exitus } & \multicolumn{2}{|c|}{ Surviving } & \multirow[b]{2}{*}{$\mathrm{X}^{2}$} & \multirow[b]{2}{*}{ p } \\
\hline & & $n$ & $\%$ & $\mathbf{n}$ & $\%$ & & \\
\hline \multirow[t]{2}{*}{ Gender } & Female & 19 & 29.2 & 14 & 31.1 & 0.045 & 0.832 \\
\hline & Male & 46 & 70.8 & 31 & 68.9 & & \\
\hline \multirow[t]{2}{*}{ Uric acid 4} & $2-4$ & 23 & 35.4 & 15 & 33.3 & 0.049 & 0.824 \\
\hline & $>4$ & 42 & 64.6 & 30 & 66.7 & & \\
\hline \multirow[t]{2}{*}{ Uric acid 6} & $2-6$ & 55 & 84.6 & 39 & 86.7 & 0.090 & 0.764 \\
\hline & $>6$ & 10 & 15.4 & 6 & 13.3 & & \\
\hline \multirow[t]{2}{*}{ Age 50} & $\leq 50$ & 5 & 7.7 & 8 & 17.8 & 2.595 & 0.107 \\
\hline & $>50$ & 60 & 92.3 & 37 & 82.2 & & \\
\hline \multirow[t]{2}{*}{ Age 70} & $\leq 70$ & 39 & 60 & 35 & 77.8 & 3.817 & 0.051 \\
\hline & $>70$ & 26 & 40 & 10 & 22.2 & & \\
\hline \multirow[t]{2}{*}{ Surgery type } & Total gastrectomy & 36 & 55.4 & ॥ & 24.4 & 10.402 & 0.001 \\
\hline & Subtotal gastrectomy & 29 & 44.6 & 34 & 75.6 & & \\
\hline \multirow[t]{4}{*}{ Pathology } & Adenocarcinoma & 48 & 73.8 & 35 & 77.8 & 0.266 & 0.966 \\
\hline & Mucinous & 2 & 3.1 & I & 2.2 & & \\
\hline & Signet cell & 13 & 20 & 8 & 17.8 & & \\
\hline & Diffuse & 2 & 3.1 & I & 2.2 & & \\
\hline \multirow[t]{4}{*}{ Localization } & Cardia & 21 & 32.3 & 5 & II.I & 10.947 & 0.007 \\
\hline & Corpus & 14 & 21.5 & 7 & 15.6 & & \\
\hline & Antrum & 28 & 43.1 & 33 & 73.3 & & \\
\hline & Whole & 2 & 3.1 & 0 & 0 & & \\
\hline \multirow[t]{2}{*}{ Size 4} & $\leq 4 \mathrm{~cm}$ & 18 & 27.7 & 27 & 60 & II.482 & 0.001 \\
\hline & $>4 \mathrm{~cm}$ & 47 & 72.3 & 18 & 40 & & \\
\hline \multirow[t]{2}{*}{ Size 8} & $\leq 8 \mathrm{~cm}$ & 47 & 72.3 & 41 & 91.1 & 5.876 & 0.015 \\
\hline & $>8 \mathrm{~cm}$ & 18 & 27.7 & 4 & 8.9 & & \\
\hline \multirow[t]{2}{*}{ Ratio 0.30} & $\leq 0.30$ & 32 & 49.2 & 34 & 75.6 & 7.678 & 0.006 \\
\hline & $>0.30$ & 33 & 50.8 & II & 24.4 & & \\
\hline \multirow{2}{*}{$\begin{array}{l}\text { Ratio } \\
0.60-0.90\end{array}$} & $\leq 0.60$ & 47 & 72.3 & 43 & 95.6 & 9.661 & 0.002 \\
\hline & $>0.60$ & 18 & 27.7 & 2 & 4.4 & & \\
\hline \multirow[t]{3}{*}{ Stage } & 1 & 2 & 3.1 & 10 & 22.2 & 24.140 & 0.001 \\
\hline & $\|$ & 12 & 18.5 & 20 & 44.4 & & \\
\hline & III & 51 & 78.5 & 15 & 33.3 & & \\
\hline
\end{tabular}

As shown in the in vitro experiments, uric acid has antioxidant properties by eliminating singlet oxygen, peroxyl radicals, and hydroxyl radicals.

This reaction of uric acid with oxidants can cause cell damage by leading to the formation of other radicals, and this creates a paradox whether it is oxidant or antioxidant. Elevated uric acid levels can cause hypertension, obesity, type 2 diabetes, dyslipidemia, renal damage, and cancer $(6,7)$. In the study by Kolonel et al. (3) solely on male subjects, while the uric acid level was found to be unrelated to stomach, colon, rectum, lung, bladder, and hematopoietic system cancers, high SUA levels were associated with prostate cancer. As a nucleic acid turnover product, uric acid increases rapidly in the growing diseased tissues of cancer patients, and this may lead to hy-

\begin{tabular}{|c|c|c|c|c|c|}
\hline & Uric Acid & Mean \pm SS & Median (Min.-Max.) & z & p \\
\hline \multirow[t]{2}{*}{ OS } & $2-4$ & $24.76 \pm 14.69$ & $24.5(2-45)$ & - & \multirow[t]{2}{*}{0.513} \\
\hline & $>4$ & $23.35 \pm|8.8|$ & $20.5(1-62)$ & 0.655 & \\
\hline \multirow[t]{2}{*}{ DFS } & $2-4$ & $22.34 \pm 15.44$ & $17(2-45)$ & - & \multirow[t]{2}{*}{0.617} \\
\hline & $>4$ & $22.54 \pm 18.85$ & $16(1-62)$ & 0.500 & \\
\hline \multirow[t]{2}{*}{ OS } & $2-6$ & $24.51 \pm 17.28$ & $24.5(1-62)$ & - & \multirow[t]{2}{*}{0.535} \\
\hline & $>6$ & $19.88 \pm 18.47$ & $12(1-45)$ & 0.620 & \\
\hline \multirow[t]{2}{*}{ DFS } & $2-6$ & $22.95 \pm 17.61$ & $19(1-62)$ & - & \multirow[t]{2}{*}{0.671} \\
\hline & $>6$ & $19.69 \pm 18.38$ & $11.5(1-45)$ & 0.424 & \\
\hline
\end{tabular}

peruricemia. SUA with an antioxidant property rich in blood is a free radical scavenger that cleans metal ions $(8,9)$. Uric acid activates proinflammatory cytokines such as extracellular signal-regulated kinase, mitogen-activated protein kinases, cyclooxygenase-2, and platelet-derived growth factor. It was shown in vivo studies in rats that increased uric acid levels are associated with vascular injury, which has been shown to cause renal damage and hypertension (10-12). As uric acid may cause hyperuricemia in cancer patients, it may also increase secretion from the kidneys due to damage to the tubules or tumor-related factors and may lead to hypouricemia (3). Increased SUA also lead to cardiovascular, respiratory, and renal diseases and metabolic syndromes $(13,14)$. Increased SUA values strengthen the inflammatory response and show both oxidant and antioxidant properties and trigger many diseases, from gout to cancer. It is claimed in cancer that it is effective in increased cell turnover and tumor lysis syndrome (15-17). While low SUA levels damage neurons, high levels provide neuroprotection by contributing to inflammation. Because of its antioxidant effects, SUA has been claimed to protect against cancer. However, studies on cancer and cancer-related mortality are showing contradictory results. While Kuo et al. (18) claim that low SUA levels are associated with cancer-related mortality, Strasak et al. (19) showed that a high SUA level is an independent risk factor for total cancer mortality (15). The relationship between cancer and SUA is complex. In their most recent meta-analysis, Dovell et al. (20) emphasized that the increase in SUA values is related to cancer. In a study of 16,000 Swedish patients with gout, it has been observed that an increased uric acid level increases the incidence of oral cavity, pharynx, colon, liver, bile duct, pancreas, lung, skin (melanoma, nonmelanoma), endometrium, and renal cancers (2I). Cetin et al. (22) suggested that high SUA levels in Stage IIIA and IIIB colorectal cancer patients may lead to early metastasis. Although Taghizadeh et al. (23) suggest that high SUA levels lead to low cancer mortality, other studies have shown that increased SUA is an independent risk factor for mortality $(19,24,25)$.

In this study, we investigated the prognostic value of SUA on DFS and OS in Stage I-III gastric cancer. In our study, both hyperuricemic and hyporuricemic SUA values were not found to be a prognostic factor in Stage I-III stomach cancer. Its impact on both DFS and OS is not statistically significant. There have not been specific studies in the literature for the relation between gastric cancer and SUA in many years, since 1946. In this 
sense, to the best of our knowledge, our work is the first in the literature, and extensive prospective randomized studies are required to explore this issue further.

Ethics Committee Approval: Ethics committee approval was received for this study from the local ethics committee of Dr.Abdurrahman Yurtaslan Training and Research Hospital (AOH 2017/10/17).

Informed Consent: Written informed consent was obtained from patients who participated in this study.

Peer-review: Externally peer-reviewed.

Author Contributions: Concept - M.A.Ü; Design - M.A.Ü,L.D.; Supervision - M.A.Ü., N.K., B.A.; Resources - M.A.Ü., L.D.; Materials - M.A.Ü., N.K., B.A.; Data Collection and/or Processing - M.A.Ü., B.A.; Analysis and/or Interpretation - M.A.Ü., N.K.; Literature Search - M.A.Ü., N.K., B.A.; Writing Manuscript-M.A.Ü.; Critical Review - L.D.; Other - B.A., N.K.

Conflict of Interest: The authors have no conflicts of interest to declare.

Financial Disclosure: The authors declared that this study has received no financial support.

\section{REFERENCES}

I. Wu XW, Muzny DM, Lee CC, Caskey CT. Two independent mutational events in the loss of urateoxidase during hominoid evolution. J Mol Evol 1992; 34(I): 78-84. [CrossRef]

2. Oda M, Satta Y, Takenaka O, Takahata N. Loss of urateoxidase activity in hominoid sandits evolutionary implications. Mol Biol Evol 2002; 19(5): 640-53. [CrossRef]

3. Kolonel LN, Yoshizawa C, Nomura AM, Stemmermann GN. Relationship of serum uric acid to cancer occurrence in a prospective male cohort. Cancer Epidemiol Biomarkers Prev 1994; 3(3): 225-8.

4. Ficarra BJ. Hiperuricemia in gastric cancer. Surgery 1946; 19: 223-8.

5. Niskanen LK, Laaksonen DE, Nyyssönen K, Alfthan G, Lakka HM, Lakka TA, et al. Uric acid level as a risk factor for cardiovascular and all cause mortality in middle-aged men: a prospective cohort study. Arch Intern Med 2004; 164(14): 1546-5I. [CrossRef]

6. Ames BN, Cathcart R, Schwiers E, Hochstein P. Uric acid provides an antioxidant defense in humans against oxidant- and radical-caused aging and cancer: a hypothesis. Proc Natl Acad Sci U S A 198I; 78(II): 6858-62. [CrossRef]

7. Sautin YY, Johnson RJ. Uric acid: the oxidant-antioxidant paradox. Nucleosides Nucleotides Nucleic Acids 2008; 27(6): 608-19. [CrossRef]

8. Glantzounis GK, Tsimoyiannis EC, Kappas AM, Galaris DA. Uric acid and oxidative stress. Curr Pharm Des 2005; II(32): 4I45-5I. [CrossRef]

9. Kang DH, Ha SK. Uric acid puzzle: dual role as antioxidant and pro-oxidant. Electrolyte Blood Press 2014; I2(I): I-6. [CrossRef]
10. Kang DH, Nakagawa T, Feng L, Watanabe S, Han L, Mazzali M, et al. A role for uric acid in the progression of renal disease. J Am Soc Nephrol 2002; I3(I2): 2888-97. [CrossRef]

II. Watanabe S, Kang DH, Feng L, Nakagawa T, Kanellis J, Lan H, et al. Uric acid, hominoid evolution, and the pathogenesis of salt-sensitivity. Hypertension 2002; 40: 355-60. [CrossRef]

12. Mazzali M, Hughes J, Kim YG, Jefferson JA, Kang DH, Gordon KL, et al. Elevated uric acid increases blood pressure in the ratby a novel crystal-independent mechanism. Hypertension 200l; 38(5): II0I-06. [CrossRef]

13. Colangelo LA, Gapstur SM, Gann PH, Dyer AR, Liu K. Colorectal cancer mortality and factors related to the insulin resistance syndrome. Cancer Epidemiol Biomarkers Prev 2002; II(4): 385-9I.

14. Horsfall LJ, Nazareth I, Petersen I. Serum uric acid and the risk of respiratory disease: a population-based cohort study. Thorax 2014 69(II): 1021-6. [CrossRef]

15. Yan S, Zhang P, Xu W, Liu Y, Wang B, Jiang T, et al. Serum Uric Acid Increases Risk of Cancer Incidence and Mortality: A Systematic Review and Meta-Analysis. Mediators Inflamm 2015; 2015: 764250. [CrossRef]

16. Baeksgaardand L, Sørensen JB. Acute tumor lysis syndrome in solid tumors-a case report and review of the literature. Cancer Chemother Pharmacol 2003; 5I(3): 187-92.

17. Sevanian A, Davies KJ, Hochstein P. Serum urate as an antioxidant for ascorbic acid. Am J Clin Nutr 1991; 54(6): II29-34. [CrossRef]

18. Kuo CF, See LC, Yu KH, Chou IJ, Chiou MJ, Luo SF. Significance of serum uric acid levels on the risk of all cause and cardiovascular mortality. Rheumatology (Oxford) 2013; 52(I): 127-34. [CrossRef]

19. Strasak AM, Rapp K, Hilbe W, Oberaigner W, Ruttmann E, Concin H, et al. Serum uric acid and risk of cancer mortality in a large prospective male cohort. Cancer Causes Control 2007; 18(9): 1021-9. [CrossRef]

20. Dovell F, Boffetta P. Serum uric acid and cancer mortality and incidence: a systematic review and meta-analysis. Eur J Cancer Prev 2018; 27(4): 399-405. [CrossRef]

21. Boffetta P, Nordenvall C, Nyrén O, Ye W. A prospective study of gout and cancer. Eur J Cancer Prev 2009; 18(2): 127-32. [CrossRef]

22. Cetin AO, Omar M, Calp S, Tunca H, Yimaz N, Ozseker B, et al. Hyperuricemia at The Time Of Diagnosis is a Factor for Poor Prognosis in PatientsWith Stage II and III Colorectal Cancer (Uric Acid and Colorectal Cancer). Asian Pac J Cancer Prev 2017; 18(2): 485-90.

23. Taghizadeh N, Vonk JM, Boezen HM. Serum uric acid levels and cancer mortality risk among males in a large general population-based cohort study. Cancer Causes Control 2014; 25(8): 107580. [CrossRef]

24. Juraschek SP, Tunstall-Pedoe H, Woodward M. Serum uric acid and the risk of mortality during 23 years follow-up in the Scottish heart health extended cohort study. Atherosclerosis 2014; 233(2): 623-9. [CrossRef]

25. Mazza A, Casiglia E, Scarpa R, Tikhonoff V, Pizziol A, Sica E, et al. Predictors of cancer mortality in elderly subjects. Eur J Epidemiol 1999; 15(5): 421-7. [CrossRef] 